\title{
Assessment of the Effectiveness of Water Sector Reforms in Performance of Water Service Providers: A Case Study of Mombasa Water Supply and Sanitation Company Limited
}

\author{
Mwikya Justina Kavuu, Mugambi Fred (PHD) \\ Jomo Kenyatta University of Agriculture and technology
}

\begin{abstract}
The study sought to assess the extent to which water sector reforms have influenced quality of service provision in Kenya with specific focus on MOWASCO. This was made necessary due to limited empirical data the study sought to establish how financial sustainability, human resource and development, corporate governance, operational optimization and product quality have affected performance at MOWASCO. A descriptive survey study of employees of the company was designed to help provide data to seal the existing research gap by assessing the contributions of each of the factors. A total of 206 respondents who were sampled from the target population using stratified random sampling methods returned 175 useful questionnaires. Data obtained was analysed quantitatively using descriptive and inferential methods with the aid of Statistical Package for Social Sciences (SPSS) version 20 computer software. Specifically, descriptive statistics in the form of frequencies, percentages, mean and standard deviation were used to show various relevant distributions while the relationship between the parameters were tested using Multiple Linear Regression (MLR). Findings indicated that corporate governance $(\beta=0.087, p=.025)$ and operational optimization $(\beta=0.215, p=.008)$ each have a positive significant influence on the performance at MOWASCO with operational optimization having the greatest influence. The influence due to financial sustainability though positive, was found to be insignificant $(\beta=0.071, p=.098)$. At the same time, the study established that human resource and development $(\beta=-0.013$, $p=.016)$ as well as product quality $(\beta=-0.029, p=.034)$ each had a significant negative influence on performance of the company, the influence due to product quality being greater. It is therefore recommended that the management of MOWASCO factor in features that would enhance the human resource and development as well as product quality to enable their turnaround and thus positive effect on the performance of the company. Additionally, it is suggested that they improve on the attributes of corporate governance as well as operational optimization to enhance their outputs on performance of MOWASCO.
\end{abstract}

Keywords: Water resources, Service providers

\section{INTRODUCTION}

Water is a critical resource whose availability and proper use is key factor for the sustainable social and economic development of any country, Kenya included. According to Mitchel (2005), adequate freshwater of good quality, is vital for the survival of all living organisms and the smooth functioning of ecosystems, communities, and economies. Similarly, GOK (2016) intimates that water is a finite and life sustaining resource. As a matter of fact, it is the basic human rights of every person to have access to sufficient, affordable water and sanitation of acceptable quality for personal, use and domestic use (WHO, 2010). It is thus the responsibility of the government to ensure that water resource is made available to all its users in homes, institutions, industries, agriculture, energy, livestock, wildlife and tourism (GOK, 2016).

To be able to meet the water resource needs of its citizens, the Government of the Republic of Kenya embarked on water sector reforms 2002 through enactment of the water Act 2002 (GOK, 2007; UN 2006, 2007). With the long-term goal of achieving the Millennium Development Goals (MDGs) especially on poverty reduction through establishment of well managed and sustainable water sector, the Act set up a framework for water sector reforms which aimed at separating management of water resources from the provision of water services (GOK, 2007). It also aimed at enhancing public and private partnership in the water management as well as ensuring community participation on the provision of water services. As such it established a well-articulated institutional and governance structure in which it established several agencies to handle different water related issues. This was 
aimed at decentralization of functions to lower levels state organs in order to enhance efficiency, decision making, and accountability and customer services to the citizens. Among the institutions set up under the water Act include water Appeal Board (WAB), water resources management Authority (WRMA) water services regulatory Board (WSRB), water services Boards (WSBS) and water services providers (WSPs).

Specifically, Mombasa Water Supply and Sanitation Company (MOWASCO) was established under the provision of the water Act 2002 as one of Water Services Providers (WSPs) with the mandate of serving the people of Mombasa (MOWASCO, 2010). The management of the company (MOWASCO) embarked on several water reforms and strategies aimed at ensuring that every resident in the Mombasa municipality has access to clean quality water for both domestic and industrial use. It aimed at ensuring that there is efficiency in the service delivery and operations of the company. The company also aimed at improving the sanitation within the municipality, increase accountability, professionalisms and self-sustainability. However empirical data on the extent to which these goals have been achieved is sparse. This study thus purposed to assess the effectiveness of the water sector reforms in the performance of water service providers with specific focus on MOWASCO.

\section{Water Resources Performance Standards}

All reforms in the developed and developing countries are aimed at ensuring that there is efficiency and sustainability in the water supply and sanitation services. Best practices evaluate the effectiveness of water sector reforms based on standards that include: product quality, customer satisfaction, employee and leadership development, operational optimization, financial viability, infrastructure stability, operational resiliency, community sustainability, water resource adequacy and stakeholder understanding and support. (OECD 2003, 2011). These performance standards measures are referred as the ten attributes to efficiency and provide a useful reference for utility managers seeking to improve organizational performance. They also provide a comprehensive framework related to water operators in regards to the infrastructure, customer satisfaction, community welfare, natural resource stewardship, and financial performance. At the same time, they are are used as the basis for improvement based on organizational objectives of water service operators.

\subsection{Product Quality and Availability}

In product quality the focus is to ensure that the water utilities are in compliance with Regulatory and environmental framework by ensuring that there is system reliability. The quality of services includes the quality of drinking water, water consumption standards and waste water requirements. The product availability would be evaluated by assessing the Service coverage, service quantity, and service provision requirement, Continuity of service, water pressure, and water quality as per World Health Organization standards (OECD 2003, 2011).

\subsection{Customer Satisfaction/ Customer Care Services}

Relative to customer satisfaction, customer service levels and feedback mechanism between the customers and the management are used as the parameter of performance measurement of water service providers (OECD, 2011). The focus in the water sector reforms is whether the water service operators provide a reliable response and affordable services in line with explicitly customer accepted service levels. The emphasis is if there is an effective customer feedback mechanism and the level of responsiveness to customer needs and emergencies is to the accepted levels of standards. In customer care services the water operators were assessed by the level of their responsibilities to their customers by providing quality services which is measured by continuity of water availability, water supply, water pressure, customer relations complaints and response time (WOP Africa, 2008).

\subsection{Human Resources Management and Development}

Human resources management and development is used as standard of measure of performance of water service providers. It is used at assessing the skills and competencies of the human resources employed by the water utilities as well as the management culture (OECD 2003, 2011). The emphasis is on the recruitment and retention of a workforce that is competent, motivated adaptive and selfworking. In assessing the competencies they also focus on the role played by the management to encourage employee continual learning and improvement. It is important to note that effective human resources management and development gives a business a competitive edge over rival firms (Graham $\&$ Benett, 1998). It leads to having a hard working and motivated work force produces excellent work 
that adds value to the enterprise. It also contributes to stability of a company. Good industrial relations encourage private investments and it is easier for the company to raise funds. Human resources management practices also cultivate common values and attitudes and norms which are shared among the employees throughout the organization and this on the other hand facilitates development of longterm strategies and plans. It is also enhances group cohesiveness and thus have an impact on organization productivity.

If the concerns for employees are matched by the concern for the customers, then it is likely that consumers will get excellent services which are sustainable. A well-motivated work force seeks to proactively further customer satisfaction. While if there is less concerns for employees satisfaction, this will lead to poor services to customers. (Cole, 2002). The parameters used performance indicators of water service providers herein include the Human Resource Utilization and Human resource development. The assessment is based on the total staff per 1000 connections and what is the percentage of labour cost to the total operating costs. The employee development is measured by assessing the staff training participation rate and total number of training programs undertaken (WOP Africa, 2008).

\subsection{Operational Optimization}

In the operational optimization, the water service operators need to exhibit efficient and acceptable levels of performance. The operations of the water service operators should ensure that their operations are timely, cost effective, and reliable and there is continuous sustainable performance improvement. The water operators should maintain high awareness of information and operational technology development. This is aimed at the operation is at optimum level and can accommodate the changing needs of the business environment.(OECD, 2011). Operation management is important for the organization to achieve their corporate strategy .It is concerned with the total pattern of decisions and actions which set the role, objectives and activities of operation so that they contribute to and support the organization business strategy. Operation optimization contributes directly to the strategic objectives. As well as helping other departments of the business and strategic business units make their own contribution to strategy (Nigel et al, 1995). The kind of products and services offered by a company are determined by the operations strategy. Operation strategy determines how goods and services are designed, produced and delivered to customer specifications in response to customer needs (Russell \&Taylor, 2003). If there is operation optimization in organization there is efficiency in the production and customer needs are satisfied accordingly.

\subsection{Financial Sustainability}

Financial viability focuses was on quality of managerial financial decisions, the formulation of supporting policies and the reliability of financial forecasting that ensure that the water service operators are self-sustaining and they are able to operate as commercial entities (OECD,2011).The aim is to establish and maintains an effective balance between long-term debt, asset values, operations and maintenance, expenditure and operating revenues. This also determines if the service provider will be in a position to initiate future investments and growth. Finance performance also measure the operational performance especially on the average tariff and unit operational cost, revenue collection ratio and period and the operating cost coverage as well as the quality of the services provided (WOP Africa, 2008). Financial performance safeguards the financial status of the services providers. It also affects the quality of service delivery and products produced by the company. As such the management needs to ensure financial sustainability of the company in order to protect the consumer's interest.

\section{RESEARCH QUESTIONS}

The study intended to address the following research questions:

1. What is the influence of financial sustainability on the performance improvement of Mombasa Water Supply and Sanitation Company?

2. What is the influence of human resources management and development practices on the performance Mombasa Water Supply and Sanitation Company?

3. What is the impact of corporate governance on the performance of the Mombasa Water Supply and Sanitation Company? 
4. How does the operational optimization affect the performance of the Mombasa Water Supply and Sanitation Company?

5. What is the influence of product quality and availability on the performance Mombasa Water Supply and Sanitation Company?

\section{RESEARCH METHODOLOGY}

\subsection{Participants and Procedure}

Participants were 175 respondents out of the 425 employees of MOWASCO. They were told that the study aimed at assessing the influence of water sector reforms on the performance of MOWASCO. They completed a questionnaire constructed by the researchers.

\subsection{Measures}

Performance of MOWASCO. Performance of MOWASCO was measured based on the respondents' rating of the organization's output relative to two metrics. A mean score of each item was computed.

Financial sustainability. Six statements were used to assess the extent to which the respondents perceived contributions financial sustainability to the organization's performance; all ratings were made on a 5-point scale (Strongly disagree=1, Strongly agree=5). A mean score of each item was computed.

Human resource and Development. Six statements were used to assess the extent to which the respondents perceived human resource and development to be to be influencing the organization's performance; all ratings were made on a 5-point scale (Strongly disagree $=1$, Strongly agree=5). A mean score of each item was computed.

Corporate governance. Eight statements were used to assess the extent to which the respondents perceived elements of corporate governance to be impacting the performance of MOWASCO; all ratings were made on a 5 -point scale $(1=$ strongly disagree, $5=$ strongly agree $)$. A mean score of each item was computed.

Operational optimization. Five statements were used to determine the extent to which elements of operational optimization was perceived to be impacting performance of MOWASCO; all ratings were made on a 5 -point scale ( $1=$ strongly disagree, $5=$ strongly agree $)$. A mean score of each item was computed.

Product quality and availability. Seven statements were used to determine the extent to which elements of product quality and availability was perceived to be impacting performance of MOWASCO; all ratings were made on a 5 -point scale $(1=$ strongly disagree, $5=$ strongly agree $)$. A mean score of each item was computed.

\section{RESUlTS AND DISCUSSION}

\subsection{Performance of MOWASCO}

The study principally sought to assess the performance of MOWASCO in order to interrogate attendant factors contributing to this level of performance. An inquiry was thus made from sampled respondents and findings were as is summarised in Table 1.

Table1. Performance of MOWASCO

\begin{tabular}{|l|l|l|}
\hline Statement & Mean & SD \\
\hline MOWASCO services to its customers are generally highly rated & 3.47 & 1.007 \\
\hline Products and services that are offered by MOWASCO are highly competitive & 3.94 & 1.029 \\
\hline Mean & $\mathbf{3 . 7 1}$ & $\mathbf{1 . 0 1 8}$ \\
\hline
\end{tabular}

Results obtained show that the overall performance of MOWASCO was mean rated at 3.71 and a standard deviation of 1.018. Specifically, the respondents were categorical that products and services that are offered by MOWASCO are highly competitive (3.94; $\mathrm{SD}=.1 .029)$ and that MOWASCO services to its customers are generally highly rated $(\mathrm{M}=3.47 ; \mathrm{SD}=1.007)$. Being more than the average, the findings imply that the performance of the entity is good according to a majority of the respondents. 


\subsection{Financial Sustainability}

The study to begin with sought to establish the influence of the reforms on financial sustainability. It thus made an inquiry on the respondents' perception of various issues related to the institution's financial status and consequently sustainability using a set of six statements, all of which were Likert scaled. The findings were as reported in Table 2.

Table2. MOWASCO Financial Status

\begin{tabular}{|l|l|l|l|}
\hline Statement & Mean & SD & Rank \\
\hline The company is financially stable & 3.00 & 1.000 & $\mathbf{6}$ \\
\hline $\begin{array}{l}\text { Adequate financial resources are allocated to enable delegated tasks and duties } \\
\text { accomplishment }\end{array}$ & 3.35 & 0.931 & $\mathbf{3}$ \\
\hline The company's revenue collection is continuously improving since its establishment & 3.29 & 1.047 & $\mathbf{4}$ \\
\hline The company has a functioning management information system in place & 4.18 & 1.131 & $\mathbf{1}$ \\
\hline The current financial position of the company has an influence on its reform agenda & 4.12 & 1.111 & $\mathbf{2}$ \\
\hline The company has invested adequate financial resources in infrastructure development & 3.18 & 0.951 & $\mathbf{5}$ \\
\hline Mean & $\mathbf{3 . 5 2}$ & $\mathbf{1 . 0 2 9}$ & \\
\hline
\end{tabular}

The results show that the influence of the reforms on functioning of the company's management information system received the highest rating $(M=4.18 ; S D=1.131)$. It was followed by the influence of the current financial position of the company relative to the reform agenda(M=4.12; $\mathrm{SD}=1.111)$ then that of adequacy of financial resources allocated to enable delegated tasks and duties accomplishment $(\mathrm{M}=3.35 ; \mathrm{SD}=0.931)$ followed by continuously improving company's revenue collection $(\mathrm{M}=3.29 ; \mathrm{SD}=1.047)$ then that of investing adequate financial resources in infrastructure development $(\mathrm{M}=3.18 ; \mathrm{SD}=0.951)$ and lastly that of the company's financial stability $(\mathrm{M}=3.00$; $\mathrm{SD}=1.000$ ) in decreasing order of influence. The elements attained an overall mean rating of 3.52 and standard deviation of 1.029 implying that a majority of the respondents acknowledged that the water sector reforms were having an influence on financial sustainability of the company. Regression analysis showed that the influence of financial sustainability on the performance of the company is positive but insignificant $(\beta=0.071 ; \mathrm{P}=0.098)$.This observation corroborates that of OECD (2003) who maintains that financial policies and procedures affect the affordability of water by households and their consumption levels. According to the organization, it also affects the tariff and strategic development of the water utilities which ultimately determines return on investments and water consumption standards as well as debt management levels.

\subsection{Human Resource and Development}

The study also sought to establish the influence of water sector reforms on human resource and development. Data obtained for the influence on specific elements of the variable were as captured in Table 3.

Table3. Human Resource and Development

\begin{tabular}{|l|l|l|l|}
\hline Statement & Mean & SD & Rank \\
\hline Company employees are hired on merit basis & 3.71 & 1.213 & $\mathbf{2}$ \\
\hline The company has employee reward and benefit policy which is satisfactory & 3.24 & 0.970 & $\mathbf{6}$ \\
\hline The company has a staff performance appraisal mechanism for all its workers & 4.06 & 1.248 & $\mathbf{1}$ \\
\hline The company has employee capacity building program for all its workers & 3.59 & 1.372 & $\mathbf{4}$ \\
\hline $\begin{array}{l}\text { I have benefited from such capacity building programs which greatly improved } \\
\text { my level of performance }\end{array}$ & 3.65 & 1.222 & $\mathbf{3}$ \\
\hline $\begin{array}{l}\text { Decentralization of functions by the company to the grassroots level has greatly } \\
\text { improved accountability and transparency in the company }\end{array}$ & 3.29 & 1.160 & $\mathbf{5}$ \\
\hline Mean & $\mathbf{3 . 5 9}$ & $\mathbf{1 . 1 9 8}$ & \\
\hline
\end{tabular}

The findings show that the fact that the company has a staff performance appraisal mechanism for all its workers was rated highest $(\mathrm{M}=4.06 ; \mathrm{SD}=1.1248)$ followed the fact that company employees are hired based on merit $(\mathrm{M}=3.71 ; \mathrm{SD}=1.213)$, then capacity building programs for individual workers aimed at improving level of performance $(\mathrm{M}=3.65 ; \mathrm{SD}=1.222)$ followed by capacity building program for all workers $(\mathrm{M}=3.59 ; \mathrm{SD}=1.372)$ then decentralization of functions by the company to the grassroots level which has greatly improved accountability and transparency $(\mathrm{M}=3.29 ; \mathrm{SD}=1.160)$ and lastly the satisfactoriness of the company's employee reward and benefit policy(M=3.24; $\mathrm{SD}=0.970)$. On the whole, the variable merited a mean rating of 3.59 out of 5 and a standard deviation of 1.198 
implying that the factor has benefited from the water sector reforms. Regression analysis showed that the influence of human resource and development is negative and significant $(\beta=-0.013$; $\mathrm{P}=0.016)$. According to Graham and Benett (1998), human resources management and development contributes to stability of a company, cultivates common values, attitudes and norms which are shared among the employees throughout the organization. This facilitates development of long-term strategies and plans. At the same time, it enhances group cohesiveness and thus has an impact on organization productivity. WOP Africa (2008) in supporting this assertion hold that well skilled and motivated staff spear the organization to high performance hence contributing positively to the overall performance of the organization.

\subsection{Corporate Governance}

Similarly, the study sought to assess the respondents' perception of the impact of water sector reforms on elements of corporate governance. The results were as is presented in Table 4.

Table4. Corporate Governance

\begin{tabular}{|l|l|l|l|}
\hline Statement & Mean & SD & Rank \\
\hline $\begin{array}{l}\text { All issues raised concerning staff are given priority in the Company planning } \\
\text { process }\end{array}$ & 3.06 & 0.966 & $\mathbf{8}$ \\
\hline $\begin{array}{l}\text { Administrators/managers always consult other staff members in critical } \\
\text { decisions in the company }\end{array}$ & 3.18 & 1.131 & $\mathbf{7}$ \\
\hline Managers' offices are always open to staff anytime during office hours & 4.00 & 1.173 & $\mathbf{4}$ \\
\hline $\begin{array}{l}\text { There are regular meetings organized to plan for departmental activities in the } \\
\text { company }\end{array}$ & 4.12 & 1.054 & $\mathbf{3}$ \\
\hline Staff members are invited /represented in all planning meetings & 3.35 & 0.996 & $\mathbf{6}$ \\
\hline Staff members interact freely as colleagues with their supervisors/managers & 3.82 & 1.185 & $\mathbf{5}$ \\
\hline The company organizes social functions aimed at enhancing interaction & 4.24 & 1.091 & $\mathbf{2}$ \\
\hline $\begin{array}{l}\text { Managers always attend social functions organized by the Company aimed at } \\
\text { enhancing interaction }\end{array}$ & 4.71 & 1.105 & $\mathbf{1}$ \\
\hline Mean & $\mathbf{3 . 8 1}$ & $\mathbf{1 . 0 8 4}$ & \\
\hline
\end{tabular}

The findings as captured in Table 4show that a majority of the respondents insisted that their managers always attend social functions organized by the company aimed at enhancing interaction $(\mathrm{M}=4.71 ; \mathrm{SD}=1.105)$, that the company organizes social functions aimed at enhancing interaction $(\mathrm{M}=4.24 ; \mathrm{SD}=1.091)$, that there are regular meetings organized to plan for departmental activities in the company $(\mathrm{M}=4.12 ; \mathrm{SD}=1.054)$ and that managers' offices are always open to staff anytime during office hours $(\mathrm{M}=4.00, \mathrm{SD}=1.173)$. Additionally, it was the contention of a majority of the respondents that staff members interact freely as colleagues with their supervisors/managers $(\mathrm{M}=3.82, \mathrm{SD}=1.185)$, that staff members are invited /represented in all planning meetings $(\mathrm{M}=3.35 ; \mathrm{SD}=0.966)$, administrators/managers always consult other staff members in critical decisions in the company $(\mathrm{M}=3.18 ; \mathrm{SD}=1.131)$ and that all issues raised concerning staff are given priority in the company planning process $(\mathrm{M}=3.06, \mathrm{SD}=0.966)$. Overall, the respondents mean rated the influence of elements of technology integration at 3.81 out of 5 and a standard deviation of 1.084 . Regression analysis showed that its influence was positive and significant $(\beta=0.087 ; \mathrm{P}=0.025)$. The results imply that a significant proportion of the respondents believe that the sector reforms have had an impact on corporate governance. According to NWIS (2011) and Butterworth (2009), good governance in any water service providers contributes towards the generation and accumulation of wealth through hard work and personal efforts. It ensures that there is existence of legal systems that provide water utilities stability and predictability. This ensures that there is economic environment in which business risks are rationally assessed hence affecting their performance.

\subsection{Operational Optimization}

Further, the state of elements of operational optimization was probed to assess gauge the attendant outcome of water sector reforms. Their responses were as is summarized in Table 5.

Table5. Operational Optimization

\begin{tabular}{|l|l|l|l|}
\hline Statement & Mean & SD & Rank \\
\hline $\begin{array}{l}\text { The quality of service and/ or products offered by the company has improved } \\
\text { since the formation of MOWASCO }\end{array}$ & 3.35 & 1.272 & $\mathbf{4}$ \\
\hline $\begin{array}{l}\text { Investment in infrastructure and technology has improved the performance of } \\
\text { the company }\end{array}$ & 3.53 & 1.231 & $\mathbf{3}$ \\
\hline
\end{tabular}


Assessment of the Effectiveness of Water Sector Reforms in Performance of Water Service Providers: A Case Study of Mombasa Water Supply and Sanitation Company Limited

\begin{tabular}{|l|l|l|l|}
\hline \hline Access to water services has improved since formation of MOWASCO & 3.12 & 1.111 & $\mathbf{5}$ \\
\hline $\begin{array}{l}\text { The company organizes outdoor activities to enlighten the public about its } \\
\text { products and services }\end{array}$ & 4.00 & 0.935 & $\mathbf{2}$ \\
\hline $\begin{array}{l}\text { A number of cases of malpractices in water service delivery sector in Mombasa } \\
\text { have been reported }\end{array}$ & 4.41 & 0.795 & $\mathbf{1}$ \\
\hline Mean & $\mathbf{3 . 6 8}$ & $\mathbf{1 . 0 6 9}$ & \\
\hline
\end{tabular}

Table 5 contains information on respondents' perception of the influence of water sector reforms on the elements of operational optimization. Respondents scored highly for reported cases of malpractices in water service delivery sector in Mombasa thus the highest mean rating of 4.41 and standard deviation of 0.795 . Similarly, a majority of the respondents were categorical that the company organizes outdoor activities to enlighten the public about its products and services $(\mathrm{M}=4.00$; $\mathrm{SD}=0.935)$, that investment in infrastructure and technology has improved the performance of the company $(\mathrm{M}=3.53, \mathrm{SD}=1.231)$, that the quality of service and/ or products offered by the company has improved since the formation of MOWASCO $(\mathrm{M}=3.35 ; \mathrm{SD}=1.272)$ and that access to water services has improved since formation of MOWASCO $(\mathrm{M}=3.12 ; \mathrm{SD}=1.111)$. Thus the element attained a mean ranking of 3.68 and standard deviation of 1.069 indicating that a majority of the respondents acknowledge that the reforms instituted are being felt by elements of this variable. Regression analysis showed that the influence of operational optimization is positive and significant $(\beta=0.215 ; \mathrm{P}=0.008)$. The findings are in tandem with those of previous researchers. Nigel et al. (1995) assert that operation optimization contributes directly to the strategic objectives as well as helping departments of the business and strategic business units make their own contribution to strategy. According to Russell and Taylor (2003), effective and efficient productions enhance the financial sustainability and consequently the performance of the organization. If there is operation optimization in organization there is efficiency in the production and customer needs are satisfied accordingly. Operation strategy determines how goods and services are designed, produced and delivered to customer specifications in response to customer needs.

\subsection{Product Quality and Availability}

Lastly, elements of product quality and availability were probed to assess the respondents' conception of the water sector reforms relative to their elements. Their responses were as is summarized in Table 6.

Table6. Product Quality and Availability

\begin{tabular}{|l|l|l|l|}
\hline Statement & Mean & SD & Rank \\
\hline The quality water provided by MOWASCO is as per WHO standards & 4.53 & 1.281 & $\mathbf{2}$ \\
\hline The water is good enough for drinking purposes & 4.82 & 1.237 & $\mathbf{1}$ \\
\hline Consumption standards of water from MOWASCO has consistently increased & 4.29 & 1.213 & $\mathbf{3}$ \\
\hline The company has consistently increased its service coverage with time & 3.71 & 1.448 & $\mathbf{4}$ \\
\hline MOWASCO services is consistently available to its customers throughout & 3.35 & 1.222 & $\mathbf{6}$ \\
\hline Service quantity of MOWASCO is high & 3.12 & 0.928 & $\mathbf{7}$ \\
\hline The company has met its waste water requirement targets & 3.53 & 1.281 & $\mathbf{5}$ \\
\hline Mean & $\mathbf{3 . 9 1}$ & $\mathbf{1 . 2 3 0}$ & \\
\hline
\end{tabular}

Table 6 contains information on respondents' perception about the influence of water sector reforms on the product quality and availability. Respondents scored highly for some of the elements. Specifically, a majority agreed that the water produced is good enough for drinking purposes thus the highest mean rating of 4.82 and standard deviation of 1.237. Similarly, a majority of the respondents were categorical that the quality water provided by MOWASCO is as per WHO standards $(\mathrm{M}=4.53$; $\mathrm{SD}=1.281$ ), that consumption standards of water from MOWASCO has consistently increased $(\mathrm{M}=4.29, \mathrm{SD}=1.213)$ and that the company has consistently increased its service coverage with time $(\mathrm{M}=3.71 ; \mathrm{SD}=1.448)$. At the same time, they alleged that the company has met its waste water requirement targets $(\mathrm{M}=3.53$; $\mathrm{SD}=1.281)$, that $\mathrm{MOWASCO}$ services is consistently available to its customers throughout $(\mathrm{M}=3.35 ; \mathrm{SD}=1.222)$ and that service quantity of MOWASCO is high $(\mathrm{M}=3.12 ; \mathrm{SD}=0.928)$. Thus the element attained a mean ranking of 3.91 and standard deviation of 1.230 implying that a majority of the respondents perceive water sector reforms to have influenced product quality and availability at MOWASCO. Regression analysis showed that its influence is negative and significant $(\beta=-0.029 ; \mathrm{P}=0.034)$. This finding is in line with those of Choi and Pucik (2005) as well as Tellis, Yin, and Niraj (2009) who observed that product quality is assumed to be of 
paramount importance to the survival and success of products. Moreover, the business press routinely cites quality as the cause of the success and failure of businesses (Mitra\& Golder, 2006).

\section{IMPLICATIONS, LimitATIONS AND CONCLUSIONS}

\subsection{Implications}

The study illustrated that various elements of water sector reforms have had an influence on the performance of MOWASCO. Since the study noted that human resource and development negatively predicts the performance of MOWASCO, the management should invest more in their human resource factors to enable a turnaround of employee contribution thus the company's performance. At the same time, product quality was found to negatively and significantly predict the performance of MOWASCO, it is advised that the management formulate and implement policies that would spur its attributes and consequently the variable output on the company performance.

\subsection{Limitations and Directions for Further Research}

The main limitation of this study rests on its quantitative methodology which mainly depended on self-report measures. Future studies should build on these by applying mixed methods as well as longitudinal studies that can track changes accompanying water sector reforms.

\subsection{Conclusion}

In general, the study provides an overview of the dynamics of water sector reforms in Kenya with specific focus on operations of MOWASCO, a water resource provider for Mombasa residents. It suggest that while corporate governance and operational optimization each positively and significantly influences the performance of the water resource provider, the influence of human resource and development as well as product quality are significantly negative. The management of MOWASCO should therefore enhance its revenue collection, investadequate financial resources in infrastructure development and invest more in their human resource for optimum performance.

\section{REFERENCES}

Government of Kenya (2007). National water services strategy. Nairobi, Government press.

Mitra, D., \& Golder, P. N. (2006). How does objective quality affect perceived quality? Short-term effects, long-term effects, and asymmetries. Marketing Science, 25(3), 230-247.

Nigel, S. Stleart, C., Harland, C.,. Alan, H., Robert J, (1995). Operation management. British library cataloguing in publication Pitman.

OECD (2003).Key issues and recommendations for consumer protection. Affordability, social protection and public participation urban water sector reform in Eastern Europe, Caucasus and central Asia. OECD publishing.

OECD (2011).Studies on water, Meeting the water Reform Challenge. OECD publishing.

Robert S. Russell, Berward W. Taylor 111 2003.Operations management. Fourth Edition: Pearson Eduction Singapore Ptc Ltd Indian Branch.

Tellis, G. J., Yin, E., \&Niraj, R. (2009). Does quality win? Network effects versus quality in high-tech markets. Journal of Marketing Research, 46(2), 135-149.

\section{AUTHORS' BIOGRAPHY}

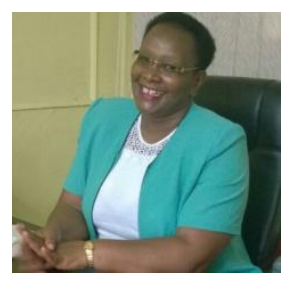

Ms Justina Kavuu Mwikya, holds a MBA (stretagic Management from Jomo Kenyatta University of Agriculture and technology. She also holds a bachelor's degree in economics and Sociology and Higher Diploma in Human resources management.

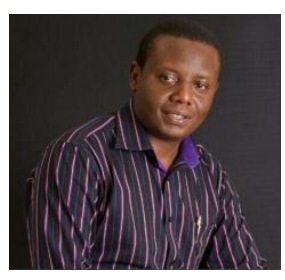

Dr Fred Mugambi from Jomo Kenyatta University of Agriculture and technology 